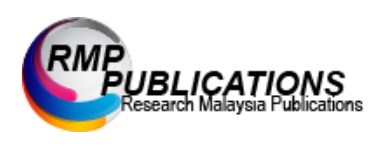

Journal of Social Science and Humanities, 4 (4): 01-05, 2021

e-ISSN: 2600 - 9056

(C) RMP Publications, 2021

DOI: $10.26666 / \mathrm{rmp} . j s s h .2021 .4 .1$

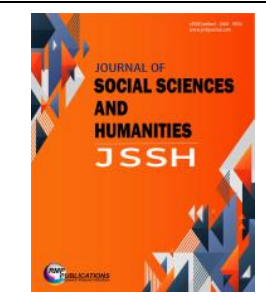

\title{
The Reviewability Of The Attorney General's Prosecutorial Discretion In Malaysia
}

\author{
Joshua Wu Kai-Ming \\ Advocate \& Solicitor of the High Court of Malaya, LL.B (Hons) London, CLP
}

\begin{abstract}
Article 145(3) of the Federal Constitution of Malaysia accords the Attorney General with prosecutorial powers. This article seeks to trace the historical development of judicial attitude towards the reviewability of the Attorney General's prosecutorial discretion. Such prosecutorial powers have, up until recently, been treated by the Courts as being an unfettered discretion on the part of the Attorney General. However, in a recent landmark decision, the Federal Court in Sundra Rajoo a/l Nadarajah v Menteri Hal Ehwal Luar Negeri, Malaysia \& 3 Ors [Federal Court Civil Appeal No. 01(f)-38-12/2020(W)] held that the Attorney General's exercise of discretion pursuant to Article 145(3) of the Federal Constitution is amenable to judicial review in appropriate circumstances.
\end{abstract}

Key words: Attorney General, Public Prosecutor, Prosecutorial Discretion, Unfettered Discretion, Federal Constitution

\section{INTRODUCTION}

In Malaysia, the Attorney General acts as the legal advisor to the Government [1] as well as the Public Prosecutor. [2]

As the Public Prosecutor, the Attorney General is the "chief criminal law enforcement officer" [3] and is "responsible for the prosecution of all criminal offences." [4]

The Attorney General's prosecutorial powers are derived from Article 145(3) of the Federal Constitution which provides that, "The Attorney General shall have power, exercisable at his discretion, to institute, conduct or discontinue any proceedings for an offence, other than proceedings before a Syariah court, a native court or a court-martial."

The Malaysian apex courts have, up until recently, consistently taken the position that the Attorney General has unfettered discretion when it comes to the exercise of his/her power under Article 145(3) of the Federal Constitution.

\section{PREVIOUS APEX COURT DECISIONS}

In Long bin Samat v Public Prosecutor [1974] 2 MLJ 152, the Appellant challenged the Attorney General's decision to charge him with a lesser offence of voluntarily causing hurt by a dangerous weapon or means (an offence under Section 324 of the Penal Code) rather than the heavier offence of voluntarily causing grievous hurt by a dangerous weapon or means (an offence under Section 326 of the Penal Code). [5]

The Federal Court in Long bin Samat (supra) acknowledged that Article 145(3) of the Federal Constitution "... clearly gives the Attorney-General very wide discretion over the control and direction of all criminal prosecutions ... Still less then would the court have power to compel him to enhance a charge when he is content to go on with a charge of a less serious nature." [6]

The Federal Court went on to remark that "anyone who is dissatisfied with the Attorney-general's decision ... should seek his remedy elsewhere, but not in the courts." [7]

Long bin Samat (supra) was affirmed by Suffian LP in Johnson Tan Han Seng $v$ Public Prosecutor \& Associated Appeals [1977] 2 MLJ 66. [8]

The Supreme Court in Public Prosecutor $v$ Zainuddin \& Anor [1986] 2 MLJ 100 expressly held that, "The law and Constitution in giving the Attorney-General an exclusive power respecting direction and control over criminal matters expect him to exercise it honestly and professionally. The law gives him a complete trust in

Corresponding Author: Joshua Wu Kai-Ming, Advocate \& Solicitor of the High Court of Malaya, LL.B (Hons) London, CLP. Email: joshua@pelim.my 
that the exercise of this power is his and his alone and that his decision is not open to any judicial review." [9]

In Karpal Singh \& Anor v Public Prosecutor [1991] 2 MLJ 544, the Supreme Court echoed sentiments similar to that in Public Prosecutor $v$ Zainuddin \& Anor [1986] 2 MLJ 100 when the former held that "the discretion vested in the Attorney General [pursuant to Article 145(3) of the Federal Constitution] is unfettered and cannot be challenged and substituted by that of the court's." [10]

More recently, the Respondent in Peguam Negara Malaysia v Chin Chee Kow (as secretary of Persatuan Kebajikan dan Amal Liam Hood Thong Chor Seng Thuan) and another appeal [2019] 4 CLJ 561 ["Chin Chee Kow"], sought to judicially review the Attorney General's exercise of discretion under Section 9(1) of the Government Proceedings Act 1950. [11]

The Federal Court, in affirming that the Attorney General has unfettered discretion in criminal matters, [12] held that "... there is no such unfettered discretion in a non-criminal matter like in [the] instant appeal." [13]

The legal position on the issue of the reviewability of the Attorney General's prosecutorial discretion appeared entrenched and settled until the Federal Court's decision in Sundra Rajoo a/l Nadarajah v Menteri Hal Ehwal Luar Negeri, Malaysia \& 3 Ors [Federal Court Civil Appeal No. 01(f)-38-12/2020(W)] ("Sundra Rajoo").

\section{SUNDRA RAJOO}

In Sundra Rajoo, Professor Datuk Dr. Sundra Rajoo a/l Nadarajah was charged in the Kuala Lumpur Sessions Court with three counts of criminal breach of trust [14] involving over RM1 million belonging to the Asian International Arbitration Centre ("AIAC"). [15]

Subsequent to the criminal charges, Professor Datuk Dr. Sundra Rajoo a/l Nadarajah filed a judicial review application in the Kuala Lumpur High Court inter alia to prohibit "the Attorney General from laying any charge or bringing any proceedings in any court in Malaysia against him with regard to anything done by him in his capacity as Director of the AIAC." [16]

Nordin bin Hassan J (now JCA) refused to grant leave to commence judicial review. [17] Amongst others, His Lordship was of the view that in light of past apex court decisions, the Attorney General's discretion pursuant to Article 145(3) was not amenable to judicial review. [18]

Rather than proceeding via judicial review, Sundra Rajoo's counsels could have "raised a preliminary objection at the Sessions Court on the basis that Sundra Rajoo has immunity under Act 485 and therefore charges should not and cannot be brought against him. The preliminary objection would have been heard first and if Sundra Rajoo was successful, the Sessions Court would not be competent to hear the criminal charges." [19]

Professor Datuk Dr. Sundra Rajoo a/l Nadarajah appealed to the Court of Appeal against the refusal of leave, and his appeal was allowed. [20] On the issue of the reviewability of the Attorney General's prosecutorial discretion, the Court of Appeal held that Chin Chee Kow represented a shift in judicial stance. [21]

The matter was then sent back to the High Court to be heard on its merits. [22]

The High Court, after hearing the merits of the judicial review application, allowed the same. [23] Mariana binti Yahya J (now JCA) opined that "... the real basis of the decision in Chin Chee 's case is that a discretionary power vested in the [Attorney General], whether by way of statute or prerogative is subject to legal limits" [24] and thus, the Attorney General's decision to initiate criminal proceedings against Professor Datuk Dr. Sundra Rajoo a/l Nadarajah "must be subject to the privileges and immunities conferred and vested upon" the latter. [25]

On appeal, the Court of Appeal reversed the High Court's decision. [26] Inter alia, the Court of Appeal was of the view that "the effect and meaning of Article 145(3) of the Federal Constitution have been settled by a long line of decisions of the apex court which have held that the decision of the Attorney General to institute or not to institute criminal proceedings is not justifiable [sic] or amenable to judicial review”. [27]

The Appellant obtained leave to appeal to the Federal Court premised on, amongst others, the following legal question:

"Whether the exercise of the Attorney
General's discretion pursuant to Article 145(3)
of the Federal Constitution is amenable to
judicial review in appropriate circumstances?"
[28]

On 30th of April 2021, the Federal Court in Sundra Rajoo answered the above leave question in the affirmative. [29]

The decision in Sundra Rajoo undoubtedly conflicts with the numerous Federal Court decisions preceding it, 
and turns the judicial status quo on Article 145(3) of the Federal Constitution on its head.

From a public law perspective, specifically in the context of accountability and check and balance, Sundra Rajoo's decision should be celebrated as it subjects even the Attorney General's prosecutorial discretion to the jurisdiction of the courts (albeit in limited circumstances).

An unfettered discretion, especially on the part of the Attorney General, would be contrary to the Rule of Law. [30]

Additionally, as the Attorney General is arguably a political appointee [31] and is unelected [32] in most cases, the courts' jurisdiction over the Attorney General's prosecutorial discretion (albeit in limited circumstances) would function as a much needed check and balance.

In its grounds of judgment, the Federal Court held that "the decision of the [Attorney General] to prefer charges against any person is an executive one. The core purpose of judicial review within the scheme of our constitutionally ordained regime of separation of powers generally presupposes that the Judiciary is constitutionally and inherently obligated to review the Executive's and/or Legislative's unlawful action or inaction. It is therefore fitting and appropriate that where it is alleged that the charge is a nullity, the proper forum to decide the question is the High Court acting within its supervisory jurisdiction." [33]

The Federal Court went on to point out that in appropriate and exceptional circumstances, quashing a decision to prosecute before the commencement of criminal proceedings would allow for the minimisation of the unncessary suffering caused to the accused. [34]

In view of Sundra Rajoo, the Attorney General's exercise of his/her prosecutorial discretion pursuant to Article 145(3) of the Federal Constitution could arguably be reviewed in cases "where the prosecutorial power is abused" [35] and/or "where its exercise contravenes constitutional protections and rights." [36]

From a constitutional law perspective, Sundra Rajoo is not necessarily inconsistent with Article 145(3) of the Federal Constitution. The latter merely provides that the Attorney General's prosecutorial powers is exercised "at his discretion."

Article 145(3) of the Federal Constitution does not provide that "no court shall have jurisdiction to entertain or determine any application, question or proceeding, in whatever form, on any ground" [37] regarding the exercise of the Attorney General's prosecutorial powers or that "the courts ... shall have no jurisdiction in respect of" [38] the same.

The learned Senior Federal Counsel acting for the respondents in Sundra Rajoo, expectedly, raised the issue of judicial review being used as a "routine tactic in criminal cases, placing another obstacle in the path of prosecution." [39]

Additionally, the learned Senior Federal Counsel also expressed her concerns of the "danger of bringing unmeritorious and tactical applications that have more to do with tripping up prosecution than a genuine desire to vindicate an accused's entitlement to a trial in accordance with the law." [40]

The Federal Court dispelled such fears and concerns by expressly stating that the proper course of dealing with a challenge to decision to prosecute lies in the subordinate courts save in "wholly exceptional circumstances." [41]

Cases from other jurisdictions which were cited by the Federal Court in support of its position also reveal a trend that "the High Court would rarely intervene in relation to prosecutorial decision-making process." [42]

Sundra Rajoo's decision represents a monumental shift in judicial attitude towards subjecting the Attorney General's prosecutorial discretion to the jurisdiction of the courts.

Although the Federal Court limited the scope of judicial review to "appropriate cases," subsequent cases will undoubtedly test the limit and scope of what amounts to an appropriate case.

\section{REFERENCES}

[1] See Article 145(2) of the Federal Constitution; see also McCosker, S. (2016). The Intersecting Professions of the International Law Adviser and Diplomat in Rising Asia: Australia, India and Malaysia. In A. Zidar \& J.-P. Gauci, (Eds.), The Role of Legal Advisers in International Law, p. 117. BRILL; Hang Tey, T. (2010). Public interest litigation in Malaysia: executive control and careful negotiation of the frontiers of judicial review. In Y. Po Jen \& L. Holning, (Eds.), Public Interest Litigation in Asia, p. 83. Routledge.

[2] Section 376(1) of the Criminal Procedure Code

[3] Abu Bakar, B. (2015). The Attorney General as Public Prosecutor in Malaysia: from QuasiJudicial to 'Executive'. IIUM Law Journal, 
23(2).

https://doi.org/10.31436/iiumlj.v23i2.188

[4] (1986). Official Year Book, p. 57. Government Press.

[5] Long bin Samat v Public Prosecutor [1974] 2 MLJ 152, at p. 152

[6] Long bin Samat v Public Prosecutor [1974] 2 MLJ 152, at p. 158

[7] Ibid.

[8] Johnson Tan Han Seng v Public Prosecutor \& Associated Appeals [1977] 2 MLJ 66, at p. 71

[9] Public Prosecutor v Zainuddin \& Anor [1986] 2 MLJ 100, at p. 103

[10] Karpal Singh \& Anor v Public Prosecutor [1991] 2 MLJ 544, at p. 548

[11] Peguam Negara Malaysia v Chin Chee Kow (as secretary of Persatuan Kebajikan dan Amal Liam Hood Thong Chor Seng Thuan) and another appeal [2019] 4 CLJ 561, at paragraph 77

[12] Peguam Negara Malaysia v Chin Chee Kow (as secretary of Persatuan Kebajikan dan Amal Liam Hood Thong Chor Seng Thuan) and another appeal [2019] 4 CLJ 561, at paragraph 29 read together with paragraph 77

[13] Ibid.

[14] Bernama. (2019, December 31). Ex-AIAC director Sundra Rajoo entitled to immunity, High Court rules. https://www.malaymail.com/news/malaysia/2 019/12/31/ex-aiac-director-sudra-rajooentitled-to-immunity-high-courtrules/1823577

[15] Karim N., Khairah. (2019, March 26). Arbitrator claims trial to 3 counts of CBT. https://www.nst.com.my/news/crimecourts/2019/03/473062/arbitrator-claims-trial3-counts-cbt

[16] Sundra Rajoo a/l Nadarajah $v$ Attorney General [2020] 3 MLJ 788, at p. 793

[17] Sundra Rajoo a/l Nadarajah v Menteri Hal Ehwal Luar Negara, Malaysia \& Ors [2019] MLJU 317, at paragraph 40

[18] Sundra Rajoo a/l Nadarajah v Menteri Hal Ehwal Luar Negara, Malaysia \& Ors [2019] MLJU 317, at paragraph 20

[19] Wu Kai-Ming, J. (2020, January 1). Commentary on Sundra Rajoo's Judicial Review Application. Retrieved June 5, 2021, from https://joshuawu.my/commentary-onsundra-rajoos-judicial-review-application/

[20] Sundra Rajoo a/l Nadarajah $v$ Attorney General [2020] 3 MLJ 788, at p. 799

[21] Sundra Rajoo a/l Nadarajah $v$ Attorney General [2020] 3 MLJ 788, at p. 796
[26] Menteri Hal Ehwal Luar Negeri, Malaysia \& Ors v Sundra Rajoo a/l Nadarajah [2021] 2 MLJ 787, at p. 820

[27] Ibid.

[28] Sundra Rajoo a/l Nadarajah v Menteri Hal Ehwal Luar Negeri, Malaysia \& 3 Ors [Federal Court Civil Appeal No. 01(f)-38-12/2020(W)], at paragraph 31

[29] Sundra Rajoo a/l Nadarajah v Menteri Hal Ehwal Luar Negeri, Malaysia \& 3 Ors [Federal Court Civil Appeal No. 01(f)-38-12/2020(W)], at paragraph 90

[30] See e.g. Pengarah Tanah Dan Galian, Wilayah Persekutuan v Sri Lempah Enterprise Sdn Bhd [1979] 1 MLJ 135, at p. 148; Wu Kai-Ming, J., \& Yoke Shan, L. (2019). Another Win for Judicial Dynamism - Peguam Negara Malaysia $v$ Chin Chee Kow, 1 (LNS(A) cxxxvi), 4; Chng Suan Tze v Minister for Home Affairs [1988] 2 SLR (R) 525, at paragraph 86; Law Society of Singapore $v$ Tan Guat Neo Phyllis [2008] 2 SLR(R) 239, at paragraph 149

[31] FMT Reporters. (2020, March 4). Tommy Thomas tells why he resigned as AG. https://www.freemalaysiatoday.com/category/ nation/2020/03/04/tommy-thomas-tells-whyhe-resigned-as-ag/; see also Buang, S. (2018, June 8). Civil servant or political appointee? https://www.nst.com.my/opinion/columnists/2 $\underline{018 / 06 / 377849 / \text { civil-servant-or-political- }}$

appointee

[32] The Attorney General can be a Member of Parliament though this is strictly not necessary. This can be inferred from Article 61(2), Article 138(2)(b), and Article 145(5) of the Federal Constitution

[33] Sundra Rajoo a/l Nadarajah v Menteri Hal Ehwal Luar Negeri, Malaysia \& 3 Ors [Federal Court Civil Appeal No. 01(f)-38-12/2020(W)], at paragraph 82

[34] Sundra Rajoo a/l Nadarajah v Menteri Hal Ehwal Luar Negeri, Malaysia \& 3 Ors [Federal Court Civil Appeal No. 01(f)-38-12/2020(W)], at paragraph 89

[35] Law Society of Singapore v Tan Guat Neo Phyllis [2008] 2 SLR(R) 239, at paragraph 149 [36] Ibid. 
[37] Such phraseology is used in Article 150(8)(b) of the Federal Constitution

[38] Such phraseology is used in Article 121(1A) of the Federal Constitution

[39] Sundra Rajoo a/l Nadarajah v Menteri Hal Ehwal Luar Negeri, Malaysia \& 3 Ors [Federal Court Civil Appeal No. 01(f)-38-12/2020(W)], at paragraph 84

[40] Ibid.

[41] Sundra Rajoo a/l Nadarajah v Menteri Hal Ehwal Luar Negeri, Malaysia \& 3 Ors [Federal Court Civil Appeal No. 01(f)-38-12/2020(W)], at paragraph 87

[42] Sundra Rajoo all Nadarajah v Menteri Hal Ehwal Luar Negeri, Malaysia \& 3 Ors

[Federal Court Civil Appeal No. 01(f)-38$12 / 2020$ (W)], at paragraph 86 